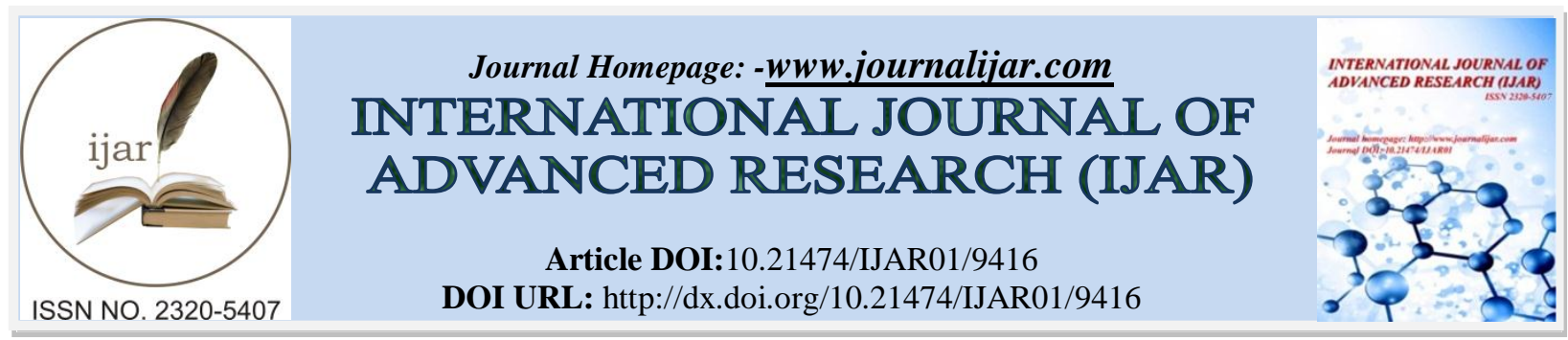

RESEARCH ARTICLE

\title{
J. M. SYNGE AND THE IRISH DRAMATIC MOVEMENT
}

\section{Indrajit Kundu ${ }^{1}$ and Dr. Mirza Maqsood Baig ${ }^{2}$.}

1. Research Scholar, Department of English, Sri Satya Sai University of Technology and Medical Sciences, Sehore, Madhya Pradesh.

2. PhD Supervisor, Department of English, Sri Satya Sai University of Technology and Medical Sciences, Sehore, Madhya Pradesh.

\section{Manuscript Info}

Manuscript History

Received: 20 May 2019

Final Accepted: 22 June 2019

Published: July 2019

\section{Abstract}

Copy Right, IJAR, 2019,. All rights reserved.

\section{Introduction:-}

Synge was a key figure in the Irish national theatre movement. When the Abbey Theatre opened in 1904, Synge was to be one of its founding directors together with Yeats and Yeats's close friend and collaborator Lady Gregory. In fact, as he was the only one of the three directors who actually lived in Dublin - with his mother, having given up his flat in Paris - he often had most to do with the day to day running of the theatre. He was very friendly with W.G. and Frank Fay, the two brothers who led the acting company; he fell in love and became engaged to the young actor Molly Algood, who used the stage name of Maire O'Neill. While Yeats and Gregory had been instrumental in conceiving and establishing the national theatre movement, Synge was the first major practicing playwright the movement produced. Along with the development of the nationalistic prose-drama or the drama of ideas, the revival of poetic drama also took place. In the beginning of the twelfth century despite the efforts of the major Victorian poets, there is no tradition of poetic drama. By 1920 there is sign of a rebirth, but the atmosphere in which realistic, naturalistic drama throve is uncongenial to poetic drama. At the Abbey theatre for years had been attempted to revive poetry on the stage but lacked the essential qualities of the dramatist. W.B. Yeats and T.S. Eliot defended poetic plays and waged on war against realistic prose drama of the modern age.

The Irish movement, also known as the Celtic Revival began a new brand in Modern drama. This movement was essentially national in character and concentrated on Irish themes and ideas. Irish drama was not intended to expose the cause of realism or naturalism. Its aim is to bring back to drama the mythology, legends and symbols of Irish life. "The imaginative idealism which has always characterized the Celtic race, the love of passionate and dreamy poetry which has exercised a fascination on the Irish mind, the belief in the fairy world which Irish people have cherished is presented in the plays produced at the Abbey Theatre. The object of the Irish dramatist is not to make people think, but to make them feel; to give the audience an emotional and spiritual uplifting such as they might experience at mass in a cathedral or at the performance of a symphony"( Castle 51). The Celtic revival in Ireland is a deliberate attempt by a group of Irishmen to give Dublin a national theatre. Ireland has provided them with stuff for their art. It is same as they have colours but not the paper to draw their thoughts. Although they believe that they are glorifying the Irish past.

The Irish Literary Revival, also nicknamed as the 'Celtic Twilight' included Irish writers like William Butler Yeats, LadyAugusta Gregory, George William Russell, John Millington Synge and Edward Martyn to stimulate a new appreciation of traditional Irish literature and Irish poetry. The Irish Celtic Revival Movement encouraged the 
creation of works written in the spirit of Irish culture, as distinct from English culture. This was due to the political need for establishing an individual Irish identity. This difference was kept alive by invoking Ireland's historic past, its myths, legends and folklore. There was an attempt to revitalize the native language and religion of Irish Celts.

Yeats was attending meetings of Irish League of the nationalist movement for freedom and Synge was travelling Germany and France still in search for his true vocation. He had thought that he should travel to Germany for the Germans naturally excelled in music and had produced great musicians and he had won a scholarship from Royal Academy of Music, Dublin. After having realized that, he could not attain the kind of excellence in music to make a mark or even earn a living by it, he came to Paris. Here he wrote some criticism of drama and poetry; he also did some translating work and taught English at the University. It was here that he met Yeats and he said to him to give up Paris and go to Aran Islands. So he made several visits to Aran Islands besides travelling the length and breadth of the country doing exactly what Yeats had suggested to him. All the major plays by J.M. Synge have at least one such factor in them which triggered the Irish national consciousness in the past. Synge's plays from their very beginning played a pivotal role in building up the traditional, cultural and religious consciousness among Irish audience.

The writers of the Irish Revival including W. B. Yeats and J. M. Synge aimed at being reacquainted with the Irish people relating their lost culture. They tried to restore their national unity through literature through themes borrowed from Irish Folklore and the ancient heroic stories. Through history Synge learnt the loss of his land and his successors understood the Irish psyche through his dramas - their desire for their lost land. Synge always dreamt of New Ireland and this vision is reflected in his plays. Synge portrayed mostly those incidents in his plays which strongly present influences of the Celtic mythology and folklore to revive the glory of the ancient Irish Celts, their beliefs and ritualistic practices.

As far as the major characters of Synge's plays are concerned, one may notice that though all of them belong to the rural peasant class or 'group' of Ireland, yet their behavioural patterns are not stereotypical. Theyturn into different personalities by the end of each play and exude a non-traditional aspect of their identity which is, in a way, 'modern.' Even in Synge's Riders to the Sea, Maurya, in the end, does not remain astereotyped rural woman who keeps on crying for the death of her only surviving son. Instead, she turns into a woman displaying courage, fortitude and an understanding of the realities of life when she says, "No man at all can be living forever, and we must be satisfied (Synge, Collected Plays 50)". InThe Well of the Saintstoo, Martin and Mary Doul transform from the simple rustic beggars to the people who 'exist' and enjoy a right to decide their own ways to lead life. They dare to deny the saint and throw away the can of holy water before his eyes. The Tinker'sWedding also, serves as an example when we see that all the characters move far beyond their set roles and not only beat the all powerful priest but also tie him in a sack. Synge's characters do come out the four walls of the set social roles and norms, but there are certain situations which compel them to behave in this way. This was unbearable for the people watching his plays' performance especially the case of Nora Burke in Shadow of the Glen and ChristyMahon in The Playboy of the Western World. Nora chose to live with a tramp seeking separation from her husband while Christy 'killed' his father to avoid his tyranny. The trouble broke out on the very first show of the play. The audience turned violent and disrupted the show by cat-calls and hissing. The next night witnessed a riot pre-planned by those who did not like the play. Police protection is sought but the chaos continued. In support of the play W.B. Yeats organized a debate in the theatre and engaged himself in a spirited discussion to fight back the allegation against the play. Even Arthur Griffith's United Irishman, the New York Gaelic American and societies like Clanna-Gael lashed out for the play being, as they found, politically offensive. They are of the opinion that the play hurt the touchy sensibilities of an aggrieved nation. The play continued to raise storm even after the death of Synge in 1909.

The Playboy of the Western World shows Synge's dramatic power at its peak. The exotic appeal of Synge's work can scarcely be exaggerated; and it is another aspect of his romantic and lyrical character. Synge himself experienced the language and life he found in the Aran Islands as something rare and strange, beautiful because it was unsophisticated, remote and elemental. It awoke the artist in him, as Paris had not been able to do, because he was a romantic. And in this Synge is the pure artist, without any admixture of the political intentions that have always to be reckoned with in Yeats and other adherents of the Celtic Renaissance. The direct sensuous consciousness of a patently picturesque speech and way of thinking is the inspiration of this play; and the point gains in importance when we consider that this is his, most ambitious work. The basis of the comic here is a delicate and capricious mockery at the very idea of fine language, closely related as it is to fine ideas. Synge plays in this comedy 
with his own discovery. Through his mock-hero Christy Mahon he allows his instrument to elaborate its most splendid ornaments. Some have been so entranced as to take it at its high face-value as sheer poetry.

W.B. Yeats suggested Synge to visit the Aran Islands to collect materials for his literary works. He hoped that the language there, rich with folk imagination would also fascinate Synge. When Synge began to draw his material from the Aran Islands he had found, by one of those accidents of fortune which sometimes save genius from extinction, the people who alone could stimulate his imagination and offer him something on which this strange combination of dramatist and nature-mystic could work. In his preface to the play he explicitly expresses his view on literature that all art is a collaboration; and there is little doubt that in the happy ages of literature, striking and beautiful phrase were as ready to the story-teller's or the playwright's hand, as the rich cloaks and dresses of his time. It is interesting to minutely note the following dialogue of Christy-

I'd be happy as the sunshine of St. Martin's Day, watching the light passing the north or the patches of fog, till I'd hear a rabbit starting to screech and I'd go running in the furze. Then, when I'd my full share, I'd come walking down where you'd see the ducks and geese stretched sleeping on the highway of the road.(32)

This speech of Christy is steeped in poetic imagination. It is brilliant for the colours, standing sharp and clear against each other and giving radiance each to each, convey, no less than the rich and glorious images and rhythms of the talk, the vitality and fertility which are the essence of the play. It is Synge's affinity of spirit rather than conscious advocacy of the revival of ancient civilization of Ireland that carries on the tradition of ancient Irish nature poetry.

J.M. Synge follows the strange life of the people who are brought up in the atmosphere quite different from the sophisticated society. The Riders to the Sea, The Shadow of the Glen and The Playboy of the Western World are the stories taken from this island. Pat Dinane, an old man told Synge the story which later came as The Shadow of the Glen. Later, he had been informed of a person who murdered his father in Connemara and fled to Inishmaan, became the basis for his The Playboy of the Western World. Riders to the Sea is again a play based on the true death of a young man, who was lamented and mourned by his relatives. Sometimes imagination may have mingled with the reality but the result of it has been always satisfactory and justified. Yeats attributed to Synge, "the true Irish heart- he lives in Aran, speaks Irish and knows the people."(57)

Through history Synge learnt the loss of his land and his successors understood the Irish psyche through his dramas - their desire for their lost land. Synge always dreamt of New Ireland and this vision is reflected in his plays. A towering contribution of Synge to the Irish Dramatic tradition would be his idyllic scenes of simple, rustic and unsophisticated folk in the unaltered originality of the countryside. Synge was very much involved with the staging of his plays which gives us a glimpse of this particular style in regard to the performance of his plays. He created a non-English atmosphere in his plays with the help of 'chanting' style of the actors while delivering dialogue. It can be said that he provided the old Celtic feel through his plays by using Irish language and style. J. M. Synge, like many Irish nationalists and literary figures of the time, took a deep interest in traditional Irish folklore and in the peasants for whom it was still an integral part of everyday life. Although not quite the mystic his friend W. B. Yeats was, Synge nevertheless felt a deep connection between folklore and nature. Much of his time on the Aran Islands was spent listening to storytellers and many of these tales went into his book The Aran Islands, where they punctuated Synge's reflections on the routines and customs of the people and the harsh natural environment of the islands. These stories also provided the basic plotlines for several of his plays. Folklores can be followed on and off in Synge's plays. Synge's characters are common peasants, fishermen, tramps, travelers and rogues and their morality is left deliberately ambiguous. Synge sought to portray the fishing community and peasant life of the Aran Islands in a realistic light. Synge closely studied the local Hiberno-English dialect and faithfully reproduced it in the plays. All of Synge's major characters are modeled on people from the peasantry, the real representatives of the Irish Celts who kept Irish mythical notions alive.

\section{Refrences:-}

1. Castle, Gregory. Modernism and the Celtic Revival. Cambridge: Cambridge University Press, 2001.Print.

2. Synge, J. M., The Aran Islands. Dublin : Maunsel and Co., 1907. Print.

3. ---. Collected Plays. Penguin Books: Harmondsworth, 1952. Print.

4. ---. Plays. Dublin: Maunsel and Roberts, 1922. Print.

5. Yeats, William Butler, ed. "Plans and Methods." Beltaine. London: Maunsel and Roberts, 1900.Print. 